\title{
Implementation of Learning Model Cooperative Learning Teams Games Tournament Collaborates With Lottery Card
}

\author{
Oktaviary Wahyu Lestari*, Nur Anita Yunikawati
}

DOI: 10.17977/um013v1i22017p99

Faculty of Economics, Universitas Negeri Malang

History Article

Received 20 April 2017

Approved 19 May 2017

Published 7 June 2017

\section{Keyword}

Cooperative Learning,

Teams Games

Tournament, Lottery

Card, The Result of the Study.

\begin{abstract}
Economic studies in class XI IPS 1 on MAN 3 Malang apply conventional learning methods and discussion groups. These methods are already focused on student learning activities, but only a few students are able to demonstrate their academic ability. The existence of these problems resulted in students who are still unable to achieve minimal competence. Therefore, needed learning models that can improve student learning outcomes. The purpose of this research was conducted to describe the learning results of students of Class XI IPS 1 MAN 3 Malang cognitive domain in economic subjects with applied learning model Cooperative Learning Teams Games Tournament collaborated with Lottery Card. The results is: 1) On cycle 1 an increase in percentage of completed learning 3.85\% when pretest become $76 \%$ when the post-test; 2) At cycle 2 an increase in percentage of completed learning $7.69 \%$ when pretest be $100 \%$ on the post-test. The first conclusion of this research is that the application of the Cooperative learning model of the Learning Teams Games Tournament collaborated with Lottery Card on economic subjects can be applied well in class XI IPS 1 MAN 3 Malang, both the application of Cooperative learning model of the Learning Teams Games Tournament collaborated with Lottery Card can improve the students learning outcomes on economic subjects of Class XI IPS 1 MAN 3 Malang.
\end{abstract}

\section{How to Cite}

Lestari, O. W., \& Yunikawati, N. A. (2017). Implementation of Learning Model Cooperative Learning Teams Games Tournament collaborates with Lottery Card. Classroom Action Research Journal, 1(2), 99-106. 


\section{INTRODUCTION}

Teaching and learning are nature and human needs. Everyone who learns will gain an understanding of daily life that is processed naturally. Learning is an activity or a process to gain knowledge, improve skills, improve behavior, attitudes, and strengthen personality (Suyono \& Hariyanto, 2012:9). Students are the subject of education especially in the learning process and the teacher is one of the educators, has an important role in learning. In the learning of teachers run its role to help and guide students to learn something that has not known without distinguishing gender, race, ethnicity, nation, religion, and social status. Teachers as implementers can provide opportunities for all students to develop teacher- and student-oriented competencies and knowledge in learning. It means that the achievement of educational goals depends on how the learning and teaching process is designed and implemented.

Economic subjects are one of the compulsory subjects that must be taken by students in high school level in IPS programs and Intercultural Economics. It is intended that students are able to think and practice critically, creatively, and familiarize themselves with the process of making rational decisions based on simplified knowledge. In the learning of teachers have made every effort to improve the quality of student learning. Teachers as educators have mastered the learning materials that will be transferred to the students, but the problems actually exist in the students themselves. Students are less active in expressing their opinions during the learning process, only a few students in a class who dare to express or dare to convey what has not been understood about the material taught, especially in economic subjects. It will also affect student learning outcomes.

Lack of student activity in the classroom is very possible will disrupt the course of learning that took place. Students receive only a small amount of knowledge from the learning activities in the classroom if the learning does not take place optimally. It certainly will affect student learning outcomes cognitive aspect, that is not meet the value of mastery learning that has been determined by the school. Problems under these circumstances must be found out by means of concrete action.

Teachers as the initiators and the implementation of learning should be good at choosing an interesting and innovative learning model so that it can arouse the spirit of student learning. A suitable learning model will keep students active with enjoyable learning conditions. Any learning model used by teachers should position students as the main focus so that the learning environment becomes less stressful and students are motivated to learn, thus improving student learning outcomes. However, not all teachers are able to apply innovative learning models because they assume that delivering the material with a lecture feels more comfortable and class conditions are easily controlled.

Problems in grade XI IPS 1 result of low student learning. Many students who are still unable to achieve the minimum competence are 75 . This is indicated by when studying tax material only 12 students who get the value above SKM. Student learning outcomes are low influenced because there are still some students who do not understand the actual material discussed so that students only rely on students who are considered mastering the material. Similarly, on the contrary, students who are more understanding of the material trying to display 
his knowledge without paying attention to a group of friends who have not mastered the material. Other groups are also so, they are still reluctant to ask or express opinions. They seem to pay attention to his friend who is presenting but not infrequently from those who have not been able to filter the information they get from the group of renderers. As a result, many of the students who are only able to remember the extent without understanding or mastering the substance of the material he studied, not infrequently encountered among those who do not remember at all what has been taught by teachers and group renderers, although the time interval in the delivery of material is not so long.

Economic learning activities in class XI IPS 1 in MAN 3 Malang has been applying conventional learning methods and group discussions where each group will discuss a subject and then present the results of the discussion. The method applied by this teacher has focused the learning activities on the students, but only a few students are able to demonstrate academic ability. This has a negative impact on student learning outcomes.

Therefore, a learning model is needed that can improve student learning outcomes. One of them by applying the learning method Cooperative Learning Teams Games Tournament collaborated with Lottery Card to improve student learning outcomes in economic subjects. This learning model not only can improve cooperation, critical thinking, and willingness to help friends who lack understanding of the material that has been taught so that their friends do not understand but each student will also show individual responsibility for the existence of individual exams that not only improve the quality of each student but also groups.

According to Slameto (2010: 2) "Learning is a process by which a person undertakes to gain a whole new behavioral change, as a result of his own experience in interaction with the environment". According to Huda (2013: 31) "In a cooperative atmosphere, each member is equally trying to achieve results that will be felt by all members of the group". According to Trianto (2010: 83) "TGT is perfect for teaching sharply formulated learning objectives with one correct answer". The advantages of the Teams Games Tournament learning model are as follows:

1. More time-boosting time for tasks.

2. Prioritize the acceptance of individual differences.

3. With a little time can master the material in depth.

4. The learning process takes place with the liveliness of the students.

5. Educate students to practice socializing with others.

6. There is an interdependence of external threats that are positive in which each group will be motivated to be better than other groups.

7. Better learning outcomes.

8. Increasing kindness, sensitivity, and tolerance.

Based on the description on the background of the problem described above, then the problem to be studied through this class action research is Application of Learning Model Cooperative Learning Teams Games Tournament Collaborated with Lottery Card to Improve Student Learning Outcomes in Economics Class XI IPS 1MAN 3 Malang Year Teaching 2015/2016. 


\section{METHOD}

The approach of this research uses a qualitative approach. The type of research used is classroom action research. This study is a study to obtain an overview of various events in the classroom such as student learning outcomes during the learning process takes place. This research was conducted in two cycles, each consisting of the plan (planing), action, observation, and reflection.

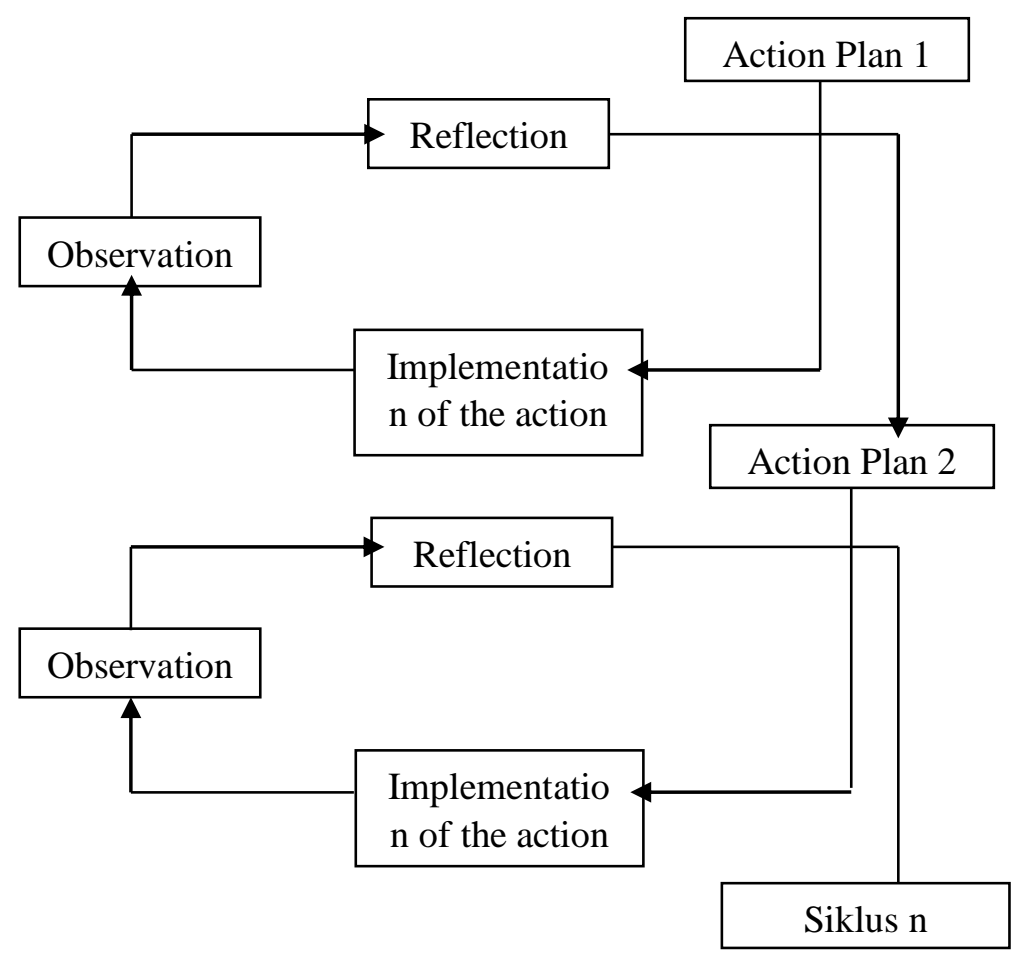

Figure 1. Research Stages

The author plays the role of planner, executor, observer, data collector, data analyzer, and report the results of his research.

Table 1. Type and Data Collection Tool

\begin{tabular}{lllll}
\hline Number & Data & Data Source & $\begin{array}{l}\text { Data Collection } \\
\text { Technique }\end{array}$ & Instrument \\
\hline 1. & $\begin{array}{l}\text { Implementation of } \\
\text { Learning Model }\end{array}$ & Student & Observation & $\begin{array}{l}\text { Observation } \\
\text { Sheet }\end{array}$ \\
& $\begin{array}{l}\text { Learning Teams } \\
\text { Games }\end{array}$ & & \\
& $\begin{array}{l}\text { Tournament } \\
\text { Collaborated with } \\
\text { Lottery Card }\end{array}$ & & \\
\hline 2. & Student Learning & Student & Test & Test sheet \\
\hline
\end{tabular}

Source: processed writer 
The instrument used in this study is the observation sheet of the implementation of learning and test given to measure student learning outcomes are cognitive aspects of cycles 1 and 2. The indicator of the success of the implementation of learning is calculated using the formula:

Table 2. Standards of Quality Achievement of Student's Cognitive Achievement

\begin{tabular}{lll}
\hline No & Percentage & Classification \\
\hline 1 & $91 \%-100 \%$ & Very good \\
2 & $75 \%-90 \%$ & Good \\
3 & $59 \%-74 \%$ & Pretty good \\
4 & $44 \%-58 \%$ & Not good \\
5 & $<43 \%$ & Not good \\
\hline
\end{tabular}

Source: modified from Arikunto (2013: 281)

The cognitive aspect learning outcomes were done with the steps, giving pretest before the learning process to measure the students' understanding of the material being studied and posttest to the students after the learning process; Comparing the students' learning outcomes of the cognitive aspects of the posttest activity on cycles 1 and 2 whether there is an increase; and describe with sentences to explain the improvement of the cognitive aspects of each cycle.

\section{RESULT AND DISCUSSION}

Implementation of action in each cycle, including preliminary, core, and closing activities. Preliminary activities are done with an opening, explanation of purpose and learning signs, and pre-test with time 20 minutes. During the lesson, observations included teacher activities in applying the TGT model in collaboration with the Lottery Card and student activities that included involvement in the learning phase of groups, games, and tournaments. While covering activities included conclusions, reflections, and post-tests at each end of the cycle.

Table 3. Percentage of Assessment Implementation in Cycle 1 and Cycle 2

\begin{tabular}{lllll}
\hline & Cycle 1 & Cycle 2 & Description & Criteria \\
\hline Meeting 1 & $83,31 \%$ & $93,63 \%$ & Increased & Very Good \\
\hline Meeting 2 & $85,7 \%$ & $95,2 \%$ & Increased & Very Good \\
\hline
\end{tabular}

Table 4. Average Student Results Class XI IPS 1 In Cycle 1 and Cycle 2

\begin{tabular}{lll}
\hline & Post Test & Description \\
\hline Cycle 1 & 78,4 & Increased \\
\hline Cycle 2 & 84,82 & \\
\hline
\end{tabular}

Tabel 5. Percentage Completeness of Students Learning Results

\begin{tabular}{lcll}
\hline & Percentage of mastery & Description & Criteria \\
\hline Cycle 1 & $76 \%$ & \multirow{2}{*}{ Increased } & Good \\
\cline { 2 - 2 } Cycle 2 & $100 \%$ & Very Good \\
\hline
\end{tabular}




\section{Application of Learning Model Cooperative Learning Teams Games Tournament Collaborated with Lottery Card}

Economic learning in class XI IPS 1 in MAN 3 Malang apply conventional learning methods and group discussions. The method has centered learning activities on the students, but only a few students are able to apply them. There are still some students who have not fully understood the material being discussed so that the students are only dependent on other students who are considered to be more in charge of the material. There are some groups who are still reluctant to ask questions or express opinions. So it can be said that in the group discussion applied in class XI IPS 1 cannot provide optimal results on learning activities. The problem is that the students who have not achieved the minimum competence. As the humanist Hubermas (in Budiningsih 2012: 73) says that new learning will occur if there is an interaction between the individual and the learning environment. Learning environment meant the natural environment and social environment.

The existence of such problems makes the author who acts as a model teacher should choose a learning model to solve the problem. Therefore, a learning model is needed that can improve student learning outcomes, one of which is learning model Cooperative Learning Teams Games Tournament collaborates with Lottery Card. This is in accordance with the statement Huda (2013: 117), Teams Games Tournament learning model is a learning model in which the class is divided into several small groups. Research on the implementation of learning model of Cooperative Learning Teams Games Tournament which collaborated with Lottery Card to improve student learning outcomes on economic subjects of students of class XI IPS 1 MAN 3 Malang implemented in 2 cycles that each consist of planning, action, observation, and reflection. This research is in accordance with the classroom action research model developed by Arikunto, et al (2009: 16).

Based on the results of field notes and practical assessment of the implementation of Cooperative Learning Teams Games Tournament learning model that collaborated with Lottery Card in cycles 1 and 2 has improved. This is because in cycle 1 model teacher with observer has done reflection activity. Where on the reflection is known some shortcomings that exist in cycle 1 so that can be fixed in cycle 2 .

Teams Games Tournament learning model makes students more active and passionate in the learning process, it is according to Slavin's opinion (2008: 167), the learning of TGT consists of five steps, five stages of class presentation, learning in teams, games, tournaments, and group awards recognition. At the stage of the game, the author as a model teacher makes Lottery Card as a learning model that can be collaborated with TGT. In accordance with constructivist approach according to Budiningsih (2012: 56-57), students are asked to build their own knowledge and experience. In accordance with the expression 
Megantorowati (2012: 3), Lottery Card is a model of learning this arisan card using a learning model that uses the card media in its application, the question card and answer cards.

Each group will discuss the material that has been taught then they make one question along with the appropriate answer to the material. In the match phase, students play the game with other team members to score for their respective teams whose games have been arranged in the form of quizzes in the form of questions relating to the subject matter. In this phase, they do matches with other group members who have the same level of ability. They have the same opportunity to read and answer the question card. Students who can answer correctly then the group will earn 10 points. After that, the group that earned the highest points will get the award from the author. Based on the assessment of the tournament by the author on cycle 1 there are some students who have not been able to answer the question correctly.

As expressed by Isjoni (2010: 12) that in Cooperative Learning, learning is said to be unfinished if one of the friends in the group has not mastered the lesson material, so the author must re-do in cycle 2. At the stage of the game, there is an increase in the number of scores obtained by each group in cycle 1 to cycle 2 . Increase in the number of scores on each group is due to cycle 2 students already understand the rules contained in the model of learning applied by the author. This is also in accordance with Johnson \& Johnson and Sutton's opinion (Trianto 2010: 60-61), that some of the elements found in cooperative learning are already in the learning model applied by the researcher ie individual responsibility and increasing interaction among students. Some group members were initially unable to correctly answer the questions at the tournament stage in cycle 1 , in cycle 2 some of them were able to answer the question correctly because they had understood the importance of interaction and individual responsibility for the success of their respective groups.

\section{Learning outcomes}

Based on the implementation of learning in cycles 1 and 2 it can be concluded that the application of Teams Games Tournament learning model in collaboration with Lottery Card can improve student learning outcomes in Economics class XI IPS 1 MAN 3 Malang. The increase is because in a cooperative atmosphere in group learning each member is equally trying to achieve learning outcomes that can be felt by all members of his group, it is in accordance with the statement Huda (2013: 31). In accordance with the opinion of Johnson \& Johnson and Sutton (Trianto 2010: 60-61), after students do cooperatively learning each group member will experience positive dependency among members so that interaction among students increases. In cooperative learning, each group member will be tested for individual interpersonal skills. So that students will have a high sense of responsibility for the success of the group. 


\section{CONCLUSION}

Application of learning model cooperative learning Teams Games Tournament collaborated with Lottery Card on economic subjects can be applied well in class XI IPS 1 MAN 3 Malang. Application of learning model Cooperative Learning Teams Games Tournament collaborated with Lottery Card can improve student learning outcomes in class XI IPS 1 MAN 3 Malang.

\section{REFERENCES}

Arikunto, S. (2009). Penelitian Tindakan Kelas. Jakarta: Bumi Aksara.

Arikunto, S. (2013). Dasar-Dasar Evaluasi Pendidikan. Jakarta: Bumi Aksara.

Budiningsih. (2012). Belajar dan Pembelajaran. Jakarta: Rineka Cipta.

Huda, M. (2013). Cooperative Learning: Metode, Teknik, Struktur dan Model Penerapan. Yogyakarta: Pustaka Pelajar.

Isjoni. (2010). Cooperative Learning Efektifitas Pembelajaran Kelompok. Bandung: Alfabeta.

Megantorowati, Puspa Tri. 2012. Penerapan Model Pembelajaran Kooperatif Teknik Kartu Arisan dalam Meningkatkan Motivasi dan Hasil Belajar Siswa. Retrieved from http://dokumen.tips/documents/penerapan-modelpembelajaran-kooperatif-teknik-kartu-arisan-dalam-meningkatkanmotivasi-dan-hasil-belajar-siswa.html.

Slameto. (2010). Belajar dan Faktor-Faktor yang Mempengaruhinya. Jakarta: Rineka Cipta.

Slavin, R. E. (2008). Cooperative Learning Teori, Riset, and Praktik. Bandung: Nusa Media.

Suyono \& Hariyanto. (2012). Belajar dan Pembelajaran. Bandung: PT Rosdakarya Remaja.

Trianto. (2010). Mengembangkan Model Pembelajaran Tematik. Jakarta: PT Prestasi Pustaka. 